\title{
Jaw Musculature of the Picini (Aves: Piciformes: Picidae)
}

\author{
Reginaldo José Donatelli \\ Laboratório de Ornitologia, Departamento de Ciências Biológicas, FC-UNESP, \\ Caixa Postal 473, 17001-970 Bauru, SP, Brazil \\ Correspondence should be addressed to Reginaldo José Donatelli, rjdonat@yahoo.com.br
}

Received 22 February 2012; Revised 16 May 2012; Accepted 16 June 2012

Academic Editor: Marie Herberstein

Copyright ( 2012 Reginaldo José Donatelli. This is an open access article distributed under the Creative Commons Attribution License, which permits unrestricted use, distribution, and reproduction in any medium, provided the original work is properly cited.

\begin{abstract}
The Picini tribe comprises 25 Old World woodpecker species grouped into seven genera that are widely distributed in Asia and include several representatives from the Eurasian region. Given the absence of detailed anatomical studies of Picini in the literature, the purposes of this study were to describe the jaw musculature of 14 species of Picini in detail and to compare the musculature patterns of these species. The results of this analysis indicate the following: (1) there is a clear association between the ventralis lateralis and dorsalis lateralis muscles through fleshy fibers that are connected in all species, (2) the jaw musculature of the genus Picus differs from that of other Picini genera in terms of the poor development of the protractor muscle system of the quadrate ( $M$. protractor quadrati and $M$. protractor pterygoidei), (3) generally, the M. pseudotemporalis superficialis originates in the ventrocaudal region of the laterosphenoid (the lower part of the orbit), with the only noteworthy exception being an origin in the upper part of the orbit in Dinopium javanense, and (4) the protractor pterygoidei muscle is more developed in Blythipicus rubiginosus, Dinopium rafflesii, and $D$. javanense than in the other species.
\end{abstract}

\section{Introduction}

The vast majority of Picini are specialized arboreal birds, but three species are primarily terrestrial (Picus viridis, P. canus, and $P$. vittatus), and one species exhibits mixed habits (P. squamatus) [1]. These three terrestrial species are widely distributed (Eurasia).Their main food sources are insects and insect larvae and eggs. These woodpeckers primarily consume ants, as well as termites, beetles, caterpillars, and other arthropods. There are also species of Picini that feed on fruit, seeds, berries (Sapheopipo noguchii), and even nectar (Chrysocolaptes lucidus).

However, regardless of their food type, the foraging methods are quite variable among the family. According to Bock [2], "the diverse genera of woodpeckers vary considerably in specialization of both their bill and their tongue; these specializations are generally independent of one another so that a particular woodpecker can have a specialized drilling bill and an unspecialized probing tongue." The same author concluded that comparative information on the morphology of woodpeckers is still lacking. The purpose of this study was to describe the jaw apparatus in several species of Picini in detail and to compare jaw morphology both between the investigated species and with the jaw morphology of other woodpecker species and bird groups. Based on the descriptive data acquired, the complexity of this apparatus will be discussed in the context of morphofunctional analyses performed by other authors.

\section{Materials and Methods}

2.1. Materials. I examined the jaw musculature of 17 Picini specimens belonging to seven species and four genera.

The material used for this investigation was obtained from the collections of the National Museum of Natural History (USNM), Smithsonian Institution, Washington, DC, USA, the Museum Zoologicum Bogoriense, Indonesian Institute of Sciences (LIPI), and the Natural History Museum of the Indonesian Institute of Sciences (MZB), Indonesia.

The species (according to Winkler and Christie, [3]), museum abbreviations, and the relative number of the specimens in the collections are listed below. All of the species preserved in $70 \%$ alcohol $\mathrm{v} / \mathrm{v}$ are from the Museum 
Zoologicum Bogoriense,Indonesian Institute of Sciences (LIPI); the type of osteological material used for the other cases is listed as follows: Reinwardtipicus validus (Temminck, 1825) LIPI MZB.Skt 119 Rv1; MZB.Skt 120 Rv2; Blythipicus rubiginosus (Swainson, 1837) LIPI MZB.Skt 117 Br1; MZB.Skt 118 Br2; USNM 489267엉 USNM 559840\%; Dinopium javanense (Ljungh, 1797) LIPI MZB.Skt 115 Dij1; MZB.Skt 116 Dij2; USNM 3180760", USNM 3180750', USNM 562041o; Dinopium rafflesii (Vigors \& Horsfield, 1830) LIPI MZB.Skt 114 Dr1; Picus mentalis Temminck, 1825 LIPI MZB.Skt 110 Pm1; MZB.Skt 110 Pm2; Picus miniaceus Pennant, 1789 LIPI MZB.Skt. 112 Pmi3; Picus puniceus Horsfield, 1821 LIPI MZB.Skt 113 Pp2.

2.2. Methods. The jaw musculature was compared, described, and drawn using a Zeiss Stemi SV11 (http://www .zeiss.com/) dissecting microscope with objective lenses that ranged from 0.4 to $6.6 \mathrm{X}$ and a fixed eyepiece magnification of 10X. Blythipicus rubiginosus was used as a reference for the comparison of several structures. All of the drawings are accompanied by legends to facilitate the observation of structures. The nomenclature that was used followed the guidelines proposed by Richards and Bock [4], but utilized several modifications that were proposed by Donatelli [5]. The species classification used was that of Winkler and Christie [3]. Table 1 summarizes the main aspects of the jaw musculature for each species.

\section{Results}

\subsection{Jaw Musculature}

3.1.1. External Mandibular Adductor System. This muscle system can be divided into three parts: rostralis, ventralis, and caudalis. The muscles of the rostralis and ventralis regions were considered strong mandibular adductors by Bock [6] because they originate "far" from the quadrate joint region; furthermore, they only act after the muscle contraction process is initiated by the action of "fast" adductors (caudalis region).

The rostralis region is structurally the most complex and can be subdivided into three sections: temporalis, medialis, and lateralis.

The temporalis section is situated between the medialis and lateralis sections and is associated with the temporal fossa, which is located in the caudolateral portion of the cranium. The insertion is associated with the coronoid process of the mandible. The medialis section is situated medially to the other sections and laterally to the muscles that constitute the internal mandibular adductor system. The medialis section is normally more developed and is associated with the upper portion of the orbit and the postorbital process. The insertions for the medialis are located on the dorsal, dorsomedial and caudolateral surfaces of the mandible. The lateralis portion is associated with the zygomatic process and exhibits an insertion with the rostrolateral and rostrodorsolateral sections of the mandible.
M. Adductor Mandibulae Externus Rostralis Temporalis. This muscle originates from poorly developed fleshy fibers (Figures $1,2,3,4$, and 5) throughout the temporal cranial fossa. These fibers have a bipinnate structure and are oriented rostrally and cross the M. a. m. e. r. lateralis fibers medially and the fibers from the deep portion of M. a. m. e. r. medialis ventrally. Some of these fibers fuse with the M. a. m. e. r. medialis fibers, while the rest are inserted into the medial and lateral narrow aponeurosis $r t 1$ (rostralis temporalis 1). Aponeurosis $r t 1$ is inserted into the pseudocoronoid 1 process of the mandible, forming a common tendon with aponeurosis rm2 (rostralis temporalis 2) from the deep portion of this muscle and aponeurosis $r m 2$ (rostralis medialis 2) from the M. a. m. e. r. medialis. Medial to this more superficial section, fleshy fibers originate from the lateral and medial portions of narrow aponeurosis $r t 1$ in the dorsorostral region of the zygomatic process. These fleshy fibers are oriented rostrally and inserted medially into aponeurosis $r t 2$, which is itself inserted into the pseudocoronoid 1 process of the mandible along with aponeuroses $r m 1$ and $r m 3$ (from M. a. m.e.r. medialis).

M. Adductor Mandibulae Externus Rostralis Medialis. The superficial portion of this muscle group originates from fleshy fibers in the dorsolateral region of the laterosphenoid (Figures 1-9). These fibers are oriented ventrorostrally for insertion into the rostromedial side of the well-developed, flattened aponeurosis rml (rostralis medialis 1). The deep portion originates from the fleshy fibers, partly on the medial region of the postorbital process and partly ventral to the fibers from the superficial portion. The deep portion is fused with the superficial portion prior to insertion into the caudomedial region of aponeurosis $r m 1$ (rostralis medialis 1). This latter is inserted into the pseudocoronoid 1 process of the mandible along with aponeuroses $r t 1$ (rostralis temporalis 1) and rt2 (rostralis temporalis 2) from M. a. m. e. r. temporalis.

M. Adductor Mandibulae Externus Rostralis Lateralis. This muscle (Figures 1, 3 and 4) originates from aponeurosis rl1 (rostralis lateralis 1) on the lateral side of the zygomatic process. The fleshy fibers arise laterally and medially to this aponeurosis and are oriented rostrally and inserted laterally into aponeurosis rl2 (rostralis lateralis 2). This muscle is inserted into the dorsal and dorsolateral regions of the mandible rostral to the insertions of aponeuroses $r t 1$ and $r t 2$ from M. a. m. e. rostralis temporalis.

M. Adductor Mandibulae Externus Ventralis. This muscle can be observed on the dorsolateral side of the mandible (Figures 1-5 and 7). It covers the M. a. m. e. r. lateralis and is located in a dorsorostral position in relation to the lateralis section of M. a. m. e. caudalis.

The M. a. m. e. ventralis originates through aponeurosis $v 1$ on the rostral side of the zygomatic process. The superficial fleshy fibers originate laterally to this aponeurosis and are oriented rostrally for insertion into the rostrolaterodorsal side of the mandible. The deep fibers originate medially to 
TABLE 1: Aspects of the jaw musculature compared among the species of the Picini.

\begin{tabular}{|c|c|c|c|c|c|c|c|}
\hline JM & B. rubiginosus & R. validus & D. javanense & D. rafflesii & P. miniaceus & P. mentalis & P. puniceus \\
\hline 1 & $\begin{array}{c}\text { Two bundles; } r t 1 \\
\text { laterally and } \\
\text { medially }\end{array}$ & $\begin{array}{l}\text { Two bundles; } r t 1 \\
\text { medially }\end{array}$ & $\begin{array}{c}\text { One bundle; } r t 1 \\
\text { laterally and } \\
\text { medially }\end{array}$ & $\begin{array}{c}\text { One bundle; } r t 1 \\
\text { laterally and } \\
\text { medially }\end{array}$ & $\begin{array}{c}\text { One bundle; } r t 1 \\
\text { laterally and } \\
\text { medially }\end{array}$ & $\begin{array}{c}\text { One bundle; } r t 1 \\
\text { laterally and } \\
\text { medially }\end{array}$ & $\begin{array}{l}\text { One bundle; } \\
\text { rt1 laterally } \\
\text { and medially }\end{array}$ \\
\hline 2 & One aponeurosis & Two aponeuroses & One aponeurosis & Two aponeuroses & $\begin{array}{c}\text { One } \\
\text { aponeurosis }\end{array}$ & $\begin{array}{c}\text { One } \\
\text { aponeurosis }\end{array}$ & $\begin{array}{c}\text { One } \\
\text { aponeurosis }\end{array}$ \\
\hline 3 & $\begin{array}{c}r l 1 \text { lateral } \\
\text { zygomatic pr. }\end{array}$ & rll dorsolateral & $\begin{array}{c}r l 1 \text { lateral } \\
\text { zygomatic pr }\end{array}$ & $\begin{array}{c}r l 1 \text { lateral } \\
\text { zygomatic pr }\end{array}$ & rll dorsolateral & rll dorsolateral & $\begin{array}{c}r l 1 \\
\text { dorsolateral }\end{array}$ \\
\hline 4 & $\begin{array}{c}\nu 1 \text { rostral } \\
\text { zygomatic process; } \\
\text { deep } \\
\text { portion-lateral } v 2\end{array}$ & $\begin{array}{l}v 1 \text { dorsocaudal } \\
\text { zygomatic process; } \\
\text { deep portion- } \\
\text { rostroventral } \\
v 2\end{array}$ & $\begin{array}{c}v 1 \text { rostral } \\
\text { zygomatic process; } \\
\text { deep } \\
\text { portion-lateral } v 2\end{array}$ & $\begin{array}{c}v 1 \text { rostral } \\
\text { zygomatic process; } \\
\text { deep } \\
\text { portion-lateral } v 2\end{array}$ & $\begin{array}{l}v 1 \text { rostral } \\
\text { zygomatic } \\
\text { process; deep } \\
\text { portion- } \\
\text { rostroventral } \\
\quad v 2\end{array}$ & $\begin{array}{l}v 1 \text { rostral } \\
\text { zygomatic } \\
\text { process; deep } \\
\text { portion- } \\
\text { rostroventral } \\
\quad v 2\end{array}$ & $\begin{array}{l}v 1 \text { rostral } \\
\text { zygomatic } \\
\text { process; deep } \\
\text { portion- } \\
\text { rostroventral } \\
\quad v 2\end{array}$ \\
\hline 5 & $\begin{array}{l}\text { cl1 from C1 crest } \\
\text { otic pr. quadrate }\end{array}$ & $\begin{array}{l}\text { cl1 from } \mathrm{Cl} \text { crest } \\
\text { otic pr. quadrate }\end{array}$ & $\begin{array}{l}\text { cl1 from C1 crest } \\
\text { otic pr. quadrate }\end{array}$ & $\begin{array}{l}\text { cl1 from } \mathrm{C} 1 \text { crest } \\
\text { otic pr. quadrate }\end{array}$ & $\begin{array}{c}\text { cl1 ventral } \\
\text { zygomatic } \\
\text { process; two } \\
\text { aponeuroses }\end{array}$ & $\begin{array}{c}\text { cl1 ventral } \\
\text { zygomatic } \\
\text { process; two } \\
\text { aponeuroses }\end{array}$ & $\begin{array}{c}\text { cl1 ventral } \\
\text { zygomatic } \\
\text { process; two } \\
\text { aponeuroses }\end{array}$ \\
\hline 6 & Aponeurosis origin & Aponeurosis origin & Aponeul & Aponeur & Fleshy origin & Fleshy origin & Fleshy origin \\
\hline 7 & $\begin{array}{l}\text { Fleshy origin; one } \\
\text { fleshy fiber }\end{array}$ & $\begin{array}{c}\text { Aponeurotic } \\
\text { origin; one fleshy } \\
\text { fiber }\end{array}$ & $\begin{array}{l}\text { Fleshy origin; one } \\
\text { fleshy fiber }\end{array}$ & $\begin{array}{l}\text { Fleshy origin; one } \\
\text { fleshy fiber }\end{array}$ & $\begin{array}{l}\text { Fleshy origin; } \\
\text { one fleshy fiber }\end{array}$ & $\begin{array}{l}\text { Fleshy origin; } \\
\text { two fleshy fibers }\end{array}$ & $\begin{array}{c}\text { Fleshy origin; } \\
\text { one fleshy } \\
\text { fiber }\end{array}$ \\
\hline 8 & $\begin{array}{l}\text { Origin: lower part } \\
\text { in the orbit }\end{array}$ & $\begin{array}{l}\text { Origin: lower part } \\
\text { in the orbit }\end{array}$ & $\begin{array}{l}\text { Origin: high part } \\
\text { in the orbit }\end{array}$ & $\begin{array}{l}\text { Origin: lower part } \\
\text { in the orbit }\end{array}$ & $\begin{array}{l}\text { Origin: lower } \\
\text { part in the orbit }\end{array}$ & $\begin{array}{l}\text { Origin: lower } \\
\text { part in the orbit }\end{array}$ & $\begin{array}{c}\text { Origin: lower } \\
\text { part in the } \\
\text { orbit }\end{array}$ \\
\hline 9 & $\begin{array}{l}\text { Double origin; } \\
\text { superficial portion: } \\
\text { origin at the } \\
\text { top-orbital process } \\
\text { of the quadrate }\end{array}$ & $\begin{array}{c}\text { Single origin; } \\
\text { superficial portion: } \\
\text { origin at the } \\
\text { top-orbital process } \\
\text { of the quadrate }\end{array}$ & $\begin{array}{l}\text { Double origin; } \\
\text { superficial portion: } \\
\text { origin-lateral } \\
\text { surface orbital } \\
\text { process of the } \\
\text { quadrate }\end{array}$ & $\begin{array}{l}\text { Double origin; } \\
\text { superficial portion: } \\
\text { origin-lateral } \\
\text { surface orbital } \\
\text { process of the } \\
\text { quadrate }\end{array}$ & $\begin{array}{l}\text { Double origin; } \\
\text { superficial } \\
\text { portion: origin } \\
\text { at the } \\
\text { top-orbital } \\
\text { process of the } \\
\text { quadrate }\end{array}$ & $\begin{array}{l}\text { Double origin; } \\
\text { superficial } \\
\text { portion: origin } \\
\text { at the } \\
\text { top-orbital } \\
\text { process of the } \\
\text { quadrate }\end{array}$ & $\begin{array}{c}\text { Double } \\
\text { origin; } \\
\text { superficial } \\
\text { portion: } \\
\text { origin at the } \\
\text { top-orbital } \\
\text { process of the } \\
\text { quadrate }\end{array}$ \\
\hline 10 & $\begin{array}{c}\text { One fleshy fibers in } \\
\text { two parts }\end{array}$ & $\begin{array}{l}\text { Two distinct } \\
\text { bundles of fleshy } \\
\text { fibers }\end{array}$ & $\begin{array}{c}\text { One fleshy fibers in } \\
\text { two parts }\end{array}$ & $\begin{array}{l}\text { One fleshy fibers in } \\
\text { two parts }\end{array}$ & $\begin{array}{l}\text { One fleshy fibers } \\
\text { in two parts }\end{array}$ & $\begin{array}{c}\text { One fleshy fibers } \\
\text { in two parts }\end{array}$ & $\begin{array}{c}\text { One fleshy } \\
\text { fibers in two } \\
\text { parts }\end{array}$ \\
\hline 11 & $\begin{array}{l}\text { Insertion: dorsal } \\
\text { process pterygoid }\end{array}$ & $\begin{array}{l}\text { Insertion: dorsal } \\
\text { process pterygoid }\end{array}$ & $\begin{array}{l}\text { Insertion: dorsal } \\
\text { process pterygoid }\end{array}$ & $\begin{array}{l}\text { Insertion: dorsal } \\
\text { process pterygoid }\end{array}$ & $\begin{array}{c}\text { Insertion: } \\
\text { dorsocaudal } \\
\text { pterygoid }\end{array}$ & $\begin{array}{c}\text { Insertion: } \\
\text { dorsocaudal } \\
\text { pterygoid } \\
\end{array}$ & $\begin{array}{l}\text { Insertion: } \\
\text { dorsocaudal } \\
\text { pterygoid }\end{array}$ \\
\hline 12 & $\begin{array}{c}\text { Two distinct } \\
\text { bundles with } \\
\text { associated } \\
\text { aponeuroses }\end{array}$ & $\begin{array}{c}\text { Two distinct } \\
\text { bundles with } \\
\text { associated } \\
\text { aponeuroses }\end{array}$ & $\begin{array}{l}\text { Two distinct } \\
\text { bundles with } \\
\text { associated } \\
\text { aponeuroses }\end{array}$ & $\begin{array}{l}\text { Three distinct } \\
\text { bundles with } \\
\text { associated } \\
\text { aponeuroses }\end{array}$ & $\begin{array}{l}\text { One bundle } \\
\text { with one } \\
\text { aponeurosis }\end{array}$ & $\begin{array}{l}\text { Two distinct } \\
\text { bundles with } \\
\text { associated } \\
\text { aponeuroses }\end{array}$ & $\begin{array}{l}\text { One bundle } \\
\text { with one } \\
\text { aponeurosis }\end{array}$ \\
\hline 13 & $\begin{array}{l}\text { Associated with } \\
\text { dorsalis lateralis }\end{array}$ & $\begin{array}{l}\text { Associated with } \\
\text { dorsalis lateralis }\end{array}$ & $\begin{array}{l}\text { Associated with } \\
\text { dorsalis lateralis; } \\
\text { venter externus }\end{array}$ & $\begin{array}{l}\text { Associated with } \\
\text { dorsalis lateralis }\end{array}$ & $\begin{array}{l}\text { Associated with } \\
\text { dorsalis lateralis }\end{array}$ & $\begin{array}{l}\text { Associated with } \\
\text { dorsalis lateralis }\end{array}$ & $\begin{array}{c}\text { Associated } \\
\text { with dorsalis } \\
\text { lateralis }\end{array}$ \\
\hline 14 & $\begin{array}{l}\text { Two distinct } \\
\text { surfaces of } \\
\text { insertion }\end{array}$ & $\begin{array}{l}\text { Two distinct } \\
\text { surfaces of } \\
\text { insertion }\end{array}$ & $\begin{array}{l}\text { Two distinct } \\
\text { surfaces of } \\
\text { insertion }\end{array}$ & $\begin{array}{l}\text { Two distinct } \\
\text { surfaces of } \\
\text { insertion }\end{array}$ & $\begin{array}{l}\text { Two distinct } \\
\text { surfaces of } \\
\text { insertion }\end{array}$ & $\begin{array}{l}\text { Two distinct } \\
\text { surfaces of } \\
\text { insertion }\end{array}$ & $\begin{array}{l}\text { Two distinct } \\
\text { surfaces of } \\
\text { insertion }\end{array}$ \\
\hline 15 & $\begin{array}{c}\text { Two aponeuroses } \\
\text { of insertion }\end{array}$ & $\begin{array}{c}\text { Two aponeuroses } \\
\text { of insertion }\end{array}$ & $\begin{array}{c}\text { Two aponeuroses } \\
\text { of insertion }\end{array}$ & $\begin{array}{c}\text { Two aponeuroses } \\
\text { of insertion }\end{array}$ & $\begin{array}{c}\text { Two } \\
\text { aponeuroses of } \\
\text { insertion }\end{array}$ & $\begin{array}{c}\text { Two } \\
\text { aponeuroses of } \\
\text { insertion }\end{array}$ & $\begin{array}{c}\text { Two } \\
\text { aponeuroses } \\
\text { of insertion }\end{array}$ \\
\hline 16 & $\begin{array}{c}\text { Intermediate } \\
\text { portion with fleshy } \\
\text { fibers }\end{array}$ & $\begin{array}{l}\text { One aponeurosis- } \\
\text { intermediate } \\
\text { portion }\end{array}$ & $\begin{array}{c}\text { Intermediate } \\
\text { portion with fleshy } \\
\text { fibers }\end{array}$ & $\begin{array}{c}\text { Intermediate } \\
\text { portion with fleshy } \\
\text { fibers }\end{array}$ & $\begin{array}{c}\text { One } \\
\text { aponeurosis- } \\
\text { intermediate } \\
\text { portion }\end{array}$ & $\begin{array}{l}\text { Intermediate } \\
\text { portion with } \\
\text { fleshy fibers }\end{array}$ & $\begin{array}{c}\text { One } \\
\text { aponeurosis- } \\
\text { intermediate } \\
\text { portion }\end{array}$ \\
\hline
\end{tabular}

JM: Jaw musculature. 1: M. adductor mandibulae externus rostralis temporalis; $2:$ M. adductor mandibulae externus rostralis medialis; 3: M. adductor mandibulae externus rostralis lateralis; 4: M. adductor mandibulae externus ventralis; 5: M. adductor mandibulae externus caudalis lateralis; 6: M. adductor mandibulae externus caudalis medials; 7: M. adductor mandibulae posterior; 8: M. pseudotemporalis superficialis; 9: M. pseudotemporalis profundus; 10: M. protractor quadrati; 11: M. protractor pterygoidei; 12: M. pterygoideus ventralis medialis; 13: M. pterygoideus ventralis lateralis; 14: M. pterygoideus dorsalis lateralis; 15: M. pterygoideus dorsalis medialis; 16: $M$. depressor mandibulae. Letters and numbers refer to aponeuroses. 


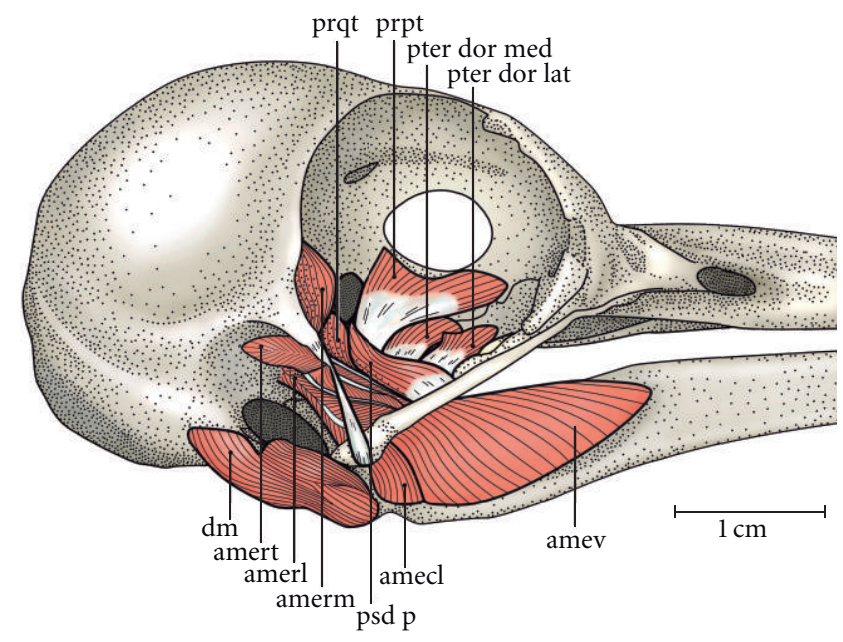

Figure 1: A lateral superficial view of the jaw muscles of Blythipicus rubiginosus. amecl: adductor mandibulae externus caudalis lateralis; amerl: adductor mandibulae externus rostralis lateralis; amerm: adductor mandibulae externus rostralis medialis; amert: adductor mandibulae externus rostralis temporalis; amev: adductor mandibulae externus ventralis; dm: depressor mandibulae; prpt: protractor pterygoidei; prqt: protractor quadrati; psd p: pseudotemporalis profundus; pter dor lat: pterygoideus dorsalis lateralis; pter dor med: pterygoideus dorsalis medialis.

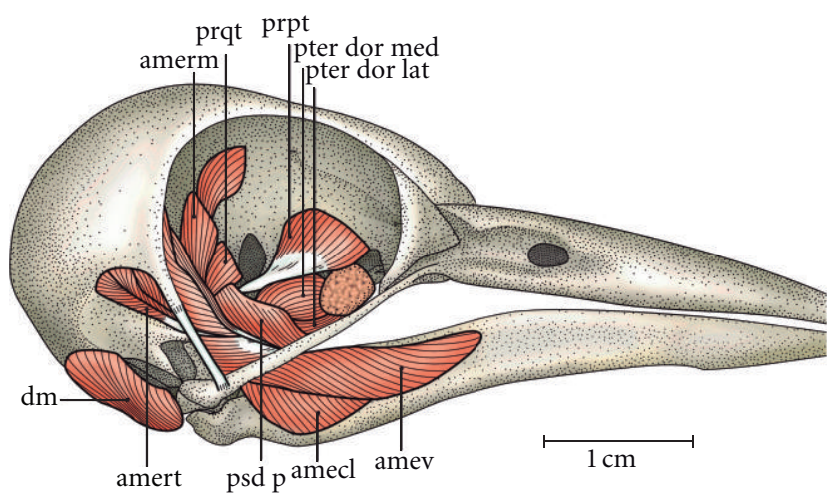

FIGURE 2: A lateral superficial view of the jaw muscles of Picus miniaceus. amecl: adductor mandibulae externus caudalis lateralis; amerm: adductor mandibulae externus rostralis medialis; amert: adductor mandibulae externus rostralis temporalis; amev: adductor mandibulae externus ventralis; dm: depressor mandibulae; prpt: protractor pterygoidei; prqt: protractor quadrati; psd p: pseudotemporalis profundus; pter dor lat: pterygoideus dorsalis lateralis; pter dor med: pterygoideus dorsalis medialis.

the superficial fibers on the lateral side of aponeurosis $v 2$, as well as on the rostral side of the same process. These fibers are oriented rostrolaterally for insertion into the lateral side of aponeurosis $v 3$ and the lateral face of the mandible.

M. Adductor Mandibulae Externus Caudalis. This muscle consists of two different sections in woodpeckers: the lateralis and the medialis. The origin of the lateralis segment is associated with the otic process of the quadrate, whereas the medialis section is associated with the otic process of the quadrate and the ventrolateral side of the laterosphenoid. The insertion sites are located on the ventrolaterocaudal, dorsal, and dorsolateral sides of the mandible. In the lateral view, these segments are located rostrally to the external auditory meatus and the M. depressor mandibulae. M. a. m. e. caudalis is considered to be a "fast" muscle (see Bock [6]) because it is one of the first to contract and raise the jaw and is located close to the quadrate articulation. The primary action of this muscle and the other adductors is the adduction of the jaw. However, this action is not solely the responsibility of these muscles, as other muscles from the internal mandibular adductor system also perform this function.

M. Adductor Mandibulae Externus Caudalis Lateralis. This muscle originates on the lateral side of the well-developed aponeurosis $\mathrm{cl} 1$ that arises in the $\mathrm{C} 1$ crest of the otic process of the quadrate that is located in its rostral portion. The fleshy fibers are arranged ventrolaterally and inserted into the laterocaudal side of the jaw, caudal to the insertion of the fleshy fibers from the M. a. m. e. ventralis (Figures 1-5).

M. Adductor Mandibulae Externus Caudalis Medialis. This muscle originates from the well-developed fleshy fibers 


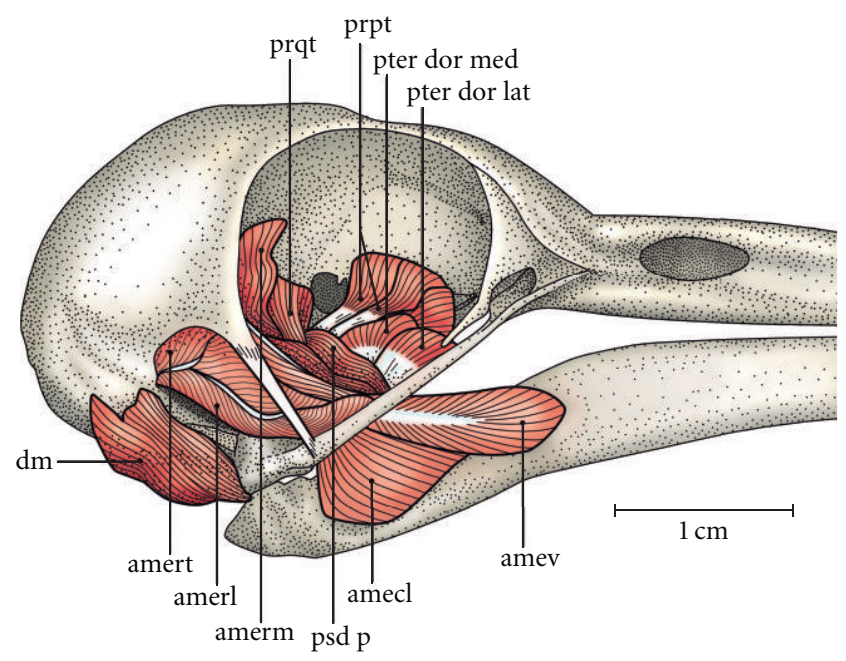

FIGURE 3: A lateral superficial view of the jaw muscles of Picus mentalis. amecl: adductor mandibulae externus caudalis lateralis; amerl: adductor mandibulae externus rostralis lateralis; amerm: adductor mandibulae externus rostralis medialis; amert: adductor mandibulae externus rostralis temporalis; amev: adductor mandibulae externus ventralis; dm: depressor mandibulae; prpt: protractor pterygoidei; prqt: protractor quadrati; psd p: pseudotemporalis profundus; pter dor lat: pterygoideus dorsalis lateralis; pter dor med: pterygoideus dorsalis medialis.

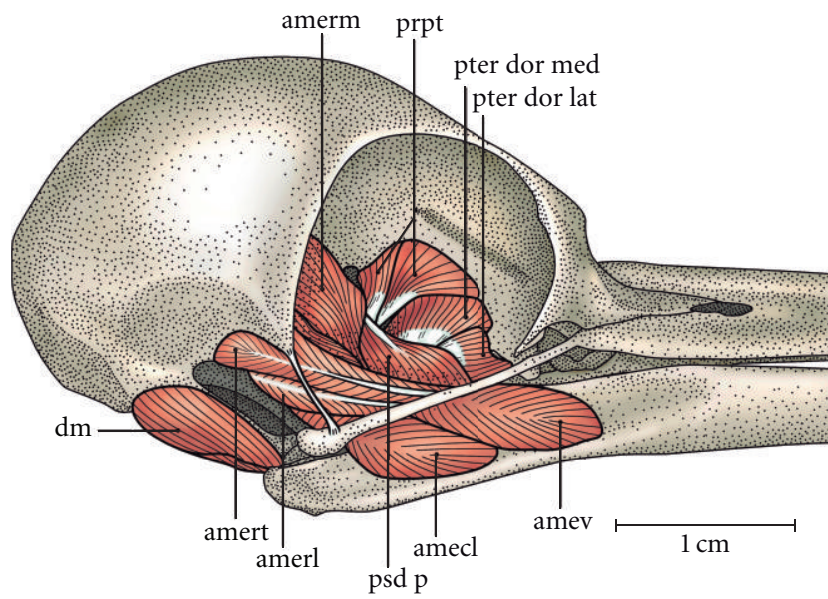

FIGURE 4: A lateral superficial view of the jaw muscles of Dinopium rafflesii. amecl: adductor mandibulae externus caudalis lateralis; amerl: adductor mandibulae externus rostralis lateralis; amerm: adductor mandibulae externus rostralis medialis; amert: adductor mandibulae externus rostralis temporalis; amev: adductor mandibulae externus ventralis; dm: depressor mandibulae; prpt: protractor pterygoidei; psd p: pseudotemporalis profundus; pter dor lat: pterygoideus dorsalis lateralis; pter dor med: pterygoideus dorsalis medialis.

and aponeurosis $\mathrm{cm} 1$ in the ventrolateral region of the laterosphenoid, ventromedial to the fleshy fibers from which the M. a. m. e. r. medialis originates and lateral to those from which the M. pseudotemporalis superficialis originates. It is not possible to visualize this muscle in the lateral view unless the M. a. m. e. r. medialis is removed. The fleshy fibers are short, oriented along the rostrocaudal axis, and inserted into the medial and lateral surfaces of aponeurosis $\mathrm{cm} 2$, which is oriented rostrally for insertion into the dorsal surface of the mandible in the pseudocoronoid process 2 and is caudal to the insertions of aponeuroses of the M. a. m. e. r. temporalis.

M. Adductor Mandibulae Posterior. This muscle is located in the proximal region of the orbital process of the quadrate and is rostromedial to the muscles of the external mandibular system and lateral to the pseudotemporalis superficialis muscle, and it is positioned caudal to the pseudotemporalis profundus muscle, which also originates in the orbital process of the quadrate. It is the most medial muscle of the external mandibular adductor system, and therefore, it is not possible to visualize this muscle in the lateral view without removing the external adductor muscles. This is the least developed of the mandibular adductors in woodpeckers.

The M. a. m. posterior arises from fleshy fibers in the quadrate body and the otic process of the quadrate. The fleshy fibers are oriented along the rostrocaudal axis, subdivided into two parts, and attached (a) directly to the medial surface of the jaw and (b) to the lateral surface of aponeuroses 


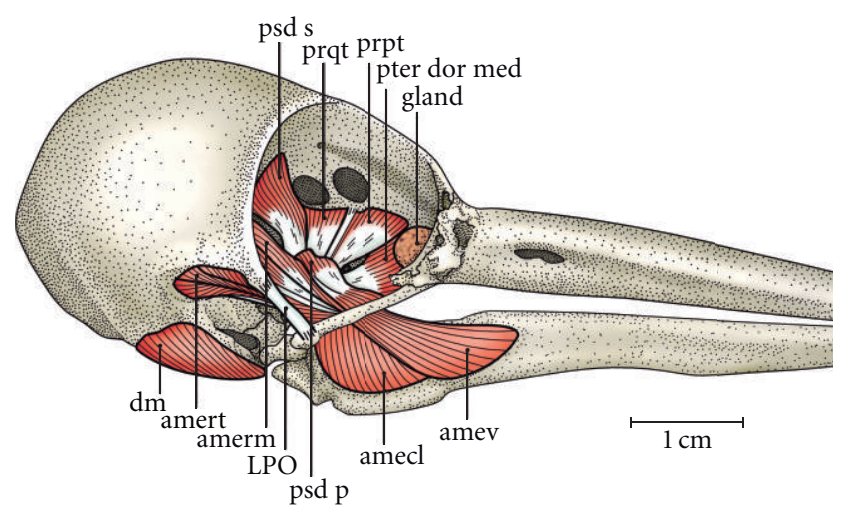

FIGURE 5: A lateral superficial view of the jaw muscles of Reindwardtipicus validus. amecl: adductor mandibulae externus caudalis lateralis; amerm: adductor mandibulae externus rostralis medialis; amert: adductor mandibulae externus rostralis temporalis; amev: adductor mandibulae externus ventralis; $\mathrm{dm}$ : depressor mandibulae; prpt: protractor pterygoidei; prqt: protractor quadrati; psd p: pseudotemporalis profundus; pter dor med: pterygoideus dorsalis medialis. LPO: postorbital ligament.

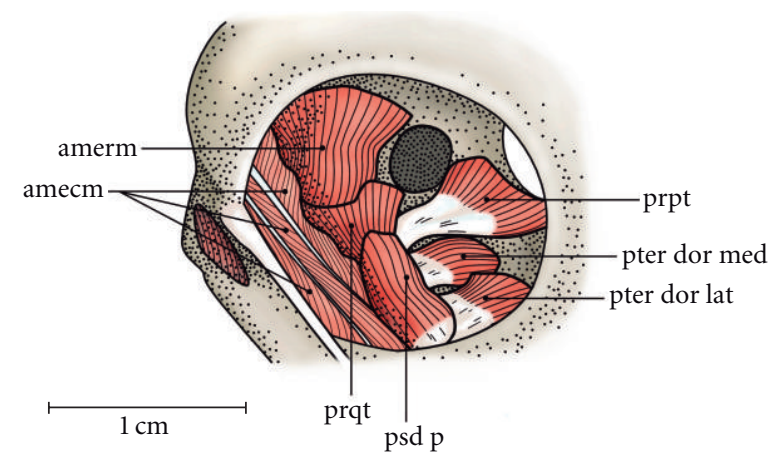

FIGURE 6: An oblique deep view of the jaw muscles of Blythipicus rubiginosus. amecl: adductor mandibulae externus caudalis medialis; amerm: adductor mandibulae externus rostralis medialis; prpt: protractor pterygoidei; prqt: protractor quadrati; psd p: pseudotemporalis profundus; pter dor lat: pterygoideus dorsalis lateralis; pter dor med: pterygoideus dorsalis medialis.

pla and p1b. These aponeuroses are oriented rostrally, with pla being inserted into the dorsal surface of the jaw close to the lateral surface and caudal to the insertions of aponeuroses $r t 1, r t 2$, and $r m 1$ on the coronoid process. Aponeurosis $p 1 \mathrm{~b}$ is inserted into the medial surface of the jaw close to the dorsal surface.

3.1.2. Internal Mandibular Adductor System. The internal mandibular adductor system consists of two muscles: $M$. pseudotemporalis superficialis (M. psd s) and M. pseudotemporalis profundus (M. psd $p$ ). The mandibular and maxillary branches of the trigeminal nerve separate the internal adductor muscles from the external adductor system muscles. These nerves pass the M. pseudotemporalis superficialis laterally, whereas the ophthalmic branch is located more rostrodorsomedially. The $M$. pseudotemporalis superficialis is associated with the lowest part of the orbit and can be seen obliquely in the orbit after removing most of the external mandibular adductor system muscles. The insertion is usually associated with the pseudotemporal tubercle of the mandible. The M. pseudotemporalis profundus is intimately associated with the orbital process of the quadrate and the medial surface of the mandible, which serves as the attachment site. It is normally a strong muscle with one or two parts and is always more developed than the M. psd superficialis. The primary action of the $M$. psd superficialis is the fast adduction of the mandible, which is also carried out by the M.a. m. e. caudalis, lateralis, and medialis muscles. The M. pseudotemporalis profundus has dual roles: it acts as both a mandibular adductor and as a retractor of the upper jaw. It is a very well-developed muscle in woodpeckers.

M. Pseudotemporalis Superficialis. This structure originates medially to the $M$. adductor mandibulae externus caudalis medialis and ventrally to the laterosphenoid (lower region of the orbit). It is a unipinnate muscle with short and poorly developed fleshy fibers that are arranged ventrally and inserted into the medial surface of aponeurosis ps1. This structure is, in turn, inserted into the pseudotemporal tubercle of the mandible close to the dorsal surface of the mandible.

M. Pseudotemporalis Profundus. The superficial portion of this muscle (Figures 1-9) originates from aponeurosis $p p 1$ and the fleshy fibers at the top of the orbital process of the quadrate. The fleshy fibers arise medially to aponeurosis $p p 1$, 


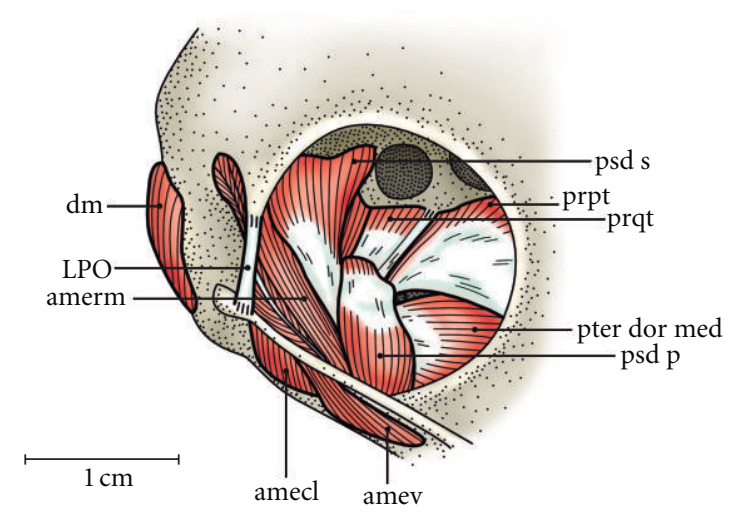

FIGURE 7: An oblique deep view of the jaw muscles of Reinwardtipicus validus. amecl: adductor mandibulae externus caudalis medialis; amerm: adductor mandibulae externus rostralis medialis; amev: adductor mandibulae externus ventralis; dm: depressor mandibulae; prpt: protractor pterygoidei; prqt: protractor quadrati; psd s: pseudotemporalis superficialis; psd p: pseudotemporalis profundus; pter dor med: pterygoideus dorsalis medialis. LPO: postorbital ligament.

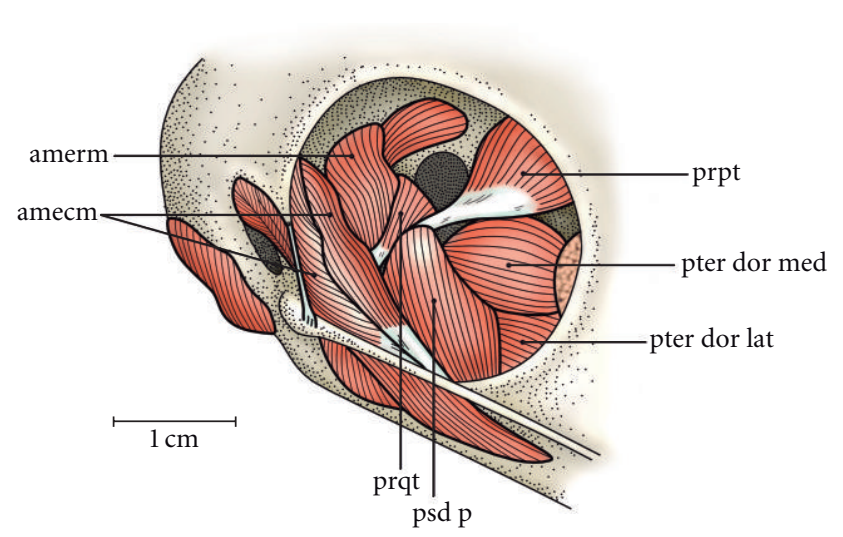

Figure 8: An oblique deep view of the jaw muscles of Picus miniaceus. amecm: adductor mandibulae externus caudalis medialis; amerm: adductor mandibulae externus rostralis medialis; prpt: protractor pterygoidei; prqt: protractor quadrati; psd p: pseudotemporalis profundus; pter dor lat: pterygoideus dorsalis lateralis; pter dor med: pterygoideus dorsalis medialis.

are obliquely arranged in the orbit, and attached to the entire medial surface of the mandible close to pseudocoronoid processes 1 and 2 . The deep portion originates medially to the anterior portion. Part of the deep portion is fused with superficial fibers, while the other part is inserted into the fleshy fibers on the medial surface of the mandible, ventral to the superficial bundles.

3.1.3. Protractor Muscle System. This system consists of two palate protractor muscles: $M$. protractor quadrati and $M$. protractor pterygoidei. Some authors consider these to be a single muscle composed of two parts [7], but woodpeckers exhibit a clear separation of the two muscles in terms of their origin and insertion. The M. protractor quadrati originates in and is located along the ventral surface of the laterosphenoid and interorbital septum, whereas the M. protractor pterygoidei is associated with the interorbital septum. These muscles are inserted respectively into the medial surface of the orbital process of the quadrate and into the dorsocaudal surface of the pterygoid. The primary and exclusive action of these muscles (i.e., they are solely responsible for this function) is to protract the upper maxilla. The mechanism by which this action occurs is described in Bock [6].

M. Protractor Quadrati ( $p t q t$ ). This structure originates from fleshy fibers in the ventrocaudal region of the interorbital septum and the ventrocaudomedial region of the laterosphenoid (Figures 1-3, and 5-9). The fleshy fibers are short, arranged obliquely in the orbit, fused before insertion, and attached to the entire medial surface of the orbital process of the quadrate and the quadratic body.

M. Protractor Pterygoidei. This muscle originates from fanshaped fleshy fibers (Figures 1-9) in the interorbital septum. These short fibers are arranged ventrally and attached to the medial surface of aponeurosis $p p 1$, which is arranged ventrally in the orbit, opened into a characteristic fan-shape, and attached to the dorsal process of the pterygoid.

3.1.4. Pterygoideus Muscle System. The pterygoideus system consists of muscles that act primarily as upper maxilla 


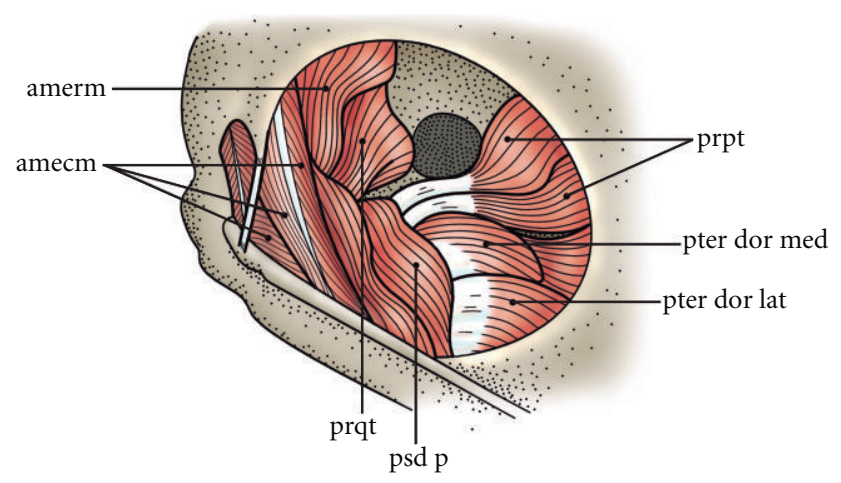

FIGURE 9: An oblique deep view of the jaw muscles of Picus mentalis. amecm: adductor mandibulae externus caudalis medialis; amerm: adductor mandibulae externus rostralis medialis; prpt: protractor pterygoidei; prqt: protractor quadrati; psd p: pseudotemporalis profundus; pter dor lat: pterygoideus dorsalis lateralis; pter dor med: pterygoideus dorsalis medialis.

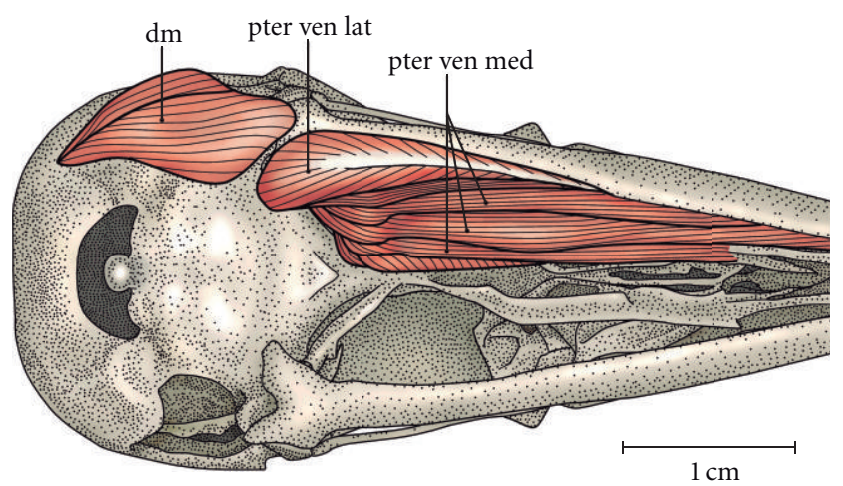

Figure 10: A ventral superficial view of the jaw muscles of Dinopium rafflesii. dm: depressor mandibulae; pter ven lat: pterygoideus ventralis lateralis; pter ven med: pterygoideus ventralis medialis.

retractors and secondarily as mandibular adductors. Its components are associated with the palatine and pterygoid at their origins and with the internal process of the mandible and the caudomedial portion of the mandible at their insertion sites. In general, authors divide this system morphologically into two different parts, ventralis and dorsalis, which are in turn subdivided into lateralis and medialis, forming a group of four different muscles.

M. Pterygoideus Ventralis Medialis. This muscle is situated on the ventral surface of the palatine medial to the pterygoideus ventralis lateralis muscle. There is a complex system of origin and insertion aponeuroses, and the latter is associated with the internal process of the mandible.

The M. pter. ven. med. arises from a well-developed aponeurosis $v m 1$ in the rostroventral region of the palatine shelf, occupying its entire extension. The fleshy fibers originate dorsally from the beginning of the aponeurosis origin in a caudal orientation, present a large muscle mass, and are inserted into the dorsal surface of the long, flattened aponeurosis $v \mathrm{~m} 2$. This aponeurosis is attached to the tip of the internal process of the mandible. Fibers also originate dorsally from aponeurosis $v m 3$ in the ventrocaudal region of the palatine shelf, dorsal to the M. pter. ven. med. fibers. These fibers are arranged caudally and inserted into two different regions: (a) directly into the medial surface of the mandible and close to its tip and (b) into the narrow aponeurosis $v m 4$, which is inserted into the tip of the internal process of the mandible along with aponeurosis $v m 2$. Thus, there are two different bundles and two aponeurotic insertions for this muscle at the tip of the internal process of the mandible and one fleshy insertion in the medial surface of the mandible.

M. Pterygoideus Ventralis Lateralis. This muscle is situated on the ventrolateral surface of the palatine shelf lateral to the anterior muscle. Its muscle fibers caudally converge with those from the pterygoideus dorsalis lateralis muscle to form a single structure before attaching to the mandible.

The M. pter. ven. lat. originates from both fleshy fibers and aponeurosis $v l 1$ at the rostrolateroventral surface of the palatine shelf (Figure 10). The fleshy fibers arise medially, are arranged caudally to the mandible, and are inserted through fleshy fibers into the caudomedial region of the mandible and the internal process of the mandible.

M. Pterygoideus Dorsalis Lateralis. This structure is situated on the dorsolateral surface of the palatine shelf, and a portion of its fibers is often fused to those of the M. pterygoideus ventralis lateralis (Figures 1-4, 6, 8, and 9). 
The superficial fleshy fibers originate at the dorsolateral and dorsal surfaces of the palatine shelf are arranged caudally and is inserted at two different points: (a) the medial surface of aponeurosis $d l 1$ (in a fan shape) and (b) the internal process of the mandible, dorsal to the M. pterygoideus ventralis lateralis fibers. Some of the dorsalis lateralis fibers are fused with those from the ventralis lateralis. The deep fibers originate at the dorsolaterocaudal surface of the palatine shelf, dorsal to aponeurosis $d l 2$. These fibers are arranged ventrally, fused with part of the fibers from the superficial portion, and attached to the lateral surface of aponeurosis $d l 3$, which is inserted into the caudomedial surface of the mandible close to the quadrate articulation.

M. Pterygoideus Dorsalis Medialis. This muscle is situated on the dorsal surface of the palatine shelf and the rostrodorsolateral surface of the pterygoid. It can be seen obliquely after the removal of the pterygoideus ventralis muscles (Figures 1-9).

The M. pter. dor. med. originates from fleshy fibers in the dorsocaudomedial region of the palatine shelf and the lateral and rostrolateral surfaces of the pterygoid (pes pterygoidei). The fleshy fibers are arranged ventrocaudally and attached to two different locations: (a) the medial surface of aponeurosis $d m 1$ and (b) the dorsocaudal surface of the internal process of the mandible. Aponeurosis $d m 1$ is inserted into the caudomedial surface of the mandible dorsal to the insertion of aponeurosis $d l 3$.

M. Depressor Mandibulae. This muscle is exclusively responsible for mandibular depression but can also perform the secondary function of protracting the upper maxilla slightly (Figures 1-5, 7, and 10).

The superficial portion of this muscle originates from fleshy fibers in the laterocaudal region of the cranium in the exoccipital region. These fibers are short, arranged ventrocaudally, and inserted into the lateral surface of aponeurosis $d p m 1$, which is inserted into the vertex angle. The intermediate portion of this muscle arises medially from fleshy fibers and is inserted into the medial surface of aponeurosis $d p m 2$, which is inserted into the medial surface of the vertex angle. The deep portion originates from the fleshy fibers in the supramatic process and is associated with the occipitomandibular ligament. The fleshy fibers are inserted throughout the caudal mandibular fossa.

Comparison (see also Table 1 for species' particularieties). Among the structural differences observed in the components of the mandibular apparatus of the Picini tribe, there are some that deserve particular attention because of their exclusiveness, their relative degree of development (greater or poorer), or other peculiarities that are present in a group of species, a genus, or a single species. I would specifically like to emphasize the following characteristics: (1) in general, the components of the external mandibular adductor system in Picini species are relatively more developed in larger species ( $R$. validus and D. rafflesii, for example); (2) there is a clear connection between the ventralis lateralis and dorsalis lateralis muscles (from the pterygoideus system) through fleshy fibers in all of the species; (3) the jaw musculature of the species from the genus Picus differs from that of the other Picini due to the relatively poor development of the quadrate protractor muscles (protractor quadrati and protractor pterygoidei); (4) the orbital process of the quadrate is relatively larger in B. rubiginosus than in the other species, while its M. pseudotemporalis profundus muscle is the least developed of all the species; (5) the muscles from the pterygoideus ventralis system are more developed in B. rubiginosus and follow the greater relative depth of the ventral palatine fossa in this species; (6) in general terms, the $M$. pseudotemporalis superficialis originates in the ventrocaudal region of the laterosphenoid (lower part of the orbit), and the only noteworthy exception is its origin in the upper part of the orbit in D. javanense; (7) the $M$. pterygoideus ventralis medialis muscle has a third component in $D$. rafflesii; (8) the protractor pterygoidei muscle is the most developed in B. rubiginosus, D. rafflesii, and D. javanense; (9) the protractor quadrati muscle is relatively more complex in $R$. validus, whereas it is more rudimentary in Dinopium species (10) there is a clear distinction between the species from the genus Picus and the other species with regards to the entire structure of the mandibular apparatus.

\section{Discussion}

The complexity of the jaw musculature of woodpeckers is evident when it is compared to the jaw musculature of other groups of birds. There are two components of the external mandibular adductor system in these species that have not been described for most groups of birds (see Bams, [8]; Beecher, [9]; Edgeworth, [10]; Hofer, [11]; Höfling and Gasc, [12]; Lakjer, [13]; Merz, [14]; Sims, [15]; Starck and Barnikol, [16]; Zusi, [17]): the adductor mandibulae externus rostralis medialis (amerm) and lateralis (amerl) muscles. The complexity is not only a matter of differences in the equivalence of the jaw musculature but also involves the development of two components of the M. adductor mandibulae externus rostralis muscle, which have been described by other authors (Burton, [18, 19]; Donatelli, [5]; Richards and Bock, [4]; van Gennip, [20]; Zusi, [21]; Zweers, [22]). These components are independent with respect to origin and insertion and combine with other adductors primarily to raise the jaw and therefore assist in the action of the remaining adductors (ventralis, caudalis, posterior- and pseudotemporalis superficialis, and psd profun$d u s$ ), indicating that their main function is to compress any type of object held by the beak [6]. The development of these muscles varies greatly among the woodpecker species investigated as well as within each species. In general, we found that these components are more developed in larger species (R. validus and D. rafflesii), but this may not be a general rule for all woodpeckers [5]. The M. pseudotemporalis superficialis is the most conservative muscle within the internal mandibular adductor system in the woodpeckers studied, but is not conservative when compared to other groups of birds [19]. In general, this muscle originates in the ventrocaudal region of the laterosphenoid (lower portion of 
the orbit), with the only notable exception being its origin in the upper part of the orbit in D. javanense. Burton [19] placed the origin of the M. pseudotemporalis superficialis in the dorsocaudal portion of the orbit or the upper part of the orbit in Coraciiformes. It has previously observed that the M. pseudotemporalis superficialis muscle is more developed in woodpeckers than in Bucconidae [19] or Galbulidae $[19,23]$. In turn, Zusi and Storer [24] noted that in the genus Podilymbus, this muscle consists of two parts with different origins and insertions: the origin of the first portion is lateral in the cranium, while the origin of the second portion is similar to that observed in other bird groups. In general, this muscle exhibits a simple unipinnate structure and functions in raising the jaw. Zusi [17] found that this muscle performs an important function that is associated with the mandibular depressor muscle in Rhynchops nigra, as it keeps the jaw rigid when the bird glides with its jaw inside the water. Zusi (op. cit.) also emphasized that this is the main mandibular adductor muscle that stabilizes the jaw, as the muscles from the external mandibular adductor system function to grasp objects (or prey) and hold them between the jaws. Bams [8] observed that the insertion aponeurosis for M. pseudotemporalis superficialis is combined with that of the adductor mandibulae externus muscle in Podiceps cristatus. Furthermore, van Gennip [20] found that this muscle has two insertion sites on the dorsal and lateral surfaces of the mandible. The orbital process of the quadrate is also an important structure in B. rubiginosus, as evidenced by its size and relative shape in comparison to other woodpeckers. However, the associated muscle, the M. pseudotemporalis profundus, is the least developed in $B$. rubiginosus among the species investigated. In contrast, the muscles from the pterygoid system (pterygoideus) are relatively more developed in this species, especially those of the pars ventralis. These muscles and the M. pseudotemporalis superficialis share the role of raising the upper jaw while the mandible is raised. Because the muscles from the pterygoideus system are more developed in B. rubiginosus, they may compensate for the poor development of the $M$. pseudotemporalis profundus.

The M. pseudotemporalis profundus exhibited substantial variation among the woodpeckers studied (see also Burton, [19]; Merz, [14]; Rooth, [25]; Zusi, [17]; Zusi and Storer, [24]). Other authors consider this muscle and the adductor mandibulae posterior to be the same muscle and refer to it as the $M$. quadratomandibularis $[11,15]$, though this situation is unlikely from both structural and functional perspectives. This muscle does not exist in Psittacidae (true parrots) [18]. Additionally, many authors consider the M. protractor quadrati and $M$. protractor pterygoidei to be the same muscle, referring to them as the $M$. protractor quadrati et pterygoidei. A possible explanation for this is the proximity of the origins of the fleshy fibers $[8,18,20]$. Burton [19] subdivided the $M$. protractor quadrati et pterygoidei into two different parts based on its origins: (1) the M. protractor quadrati 1, which originates in the caudal portion of the interorbital septum, and (2) the $M$. protractor quadrati 2 , which originates in the ventromedial region of the orbit. However, a clear distinction between the two muscles was found in woodpeckers from
Neotropical and Afrotropical regions [5], as well as in the woodpeckers in this study. The distinction arises from the fact that the origin of the M. protractor pterygoidei could be one of two different areas (the rostral area of the interorbital septum or rostroventrally to the optic foramen) and the fact that the origin of the M. protractor quadrati can be one of two different areas (the ventrocaudal area of the interorbital septum and the ventrocaudomedial area of the laterosphenoid). This indicates that they represent two separate muscles in terms of origin as well as insertion, despite performing the same function. Other authors have also considered these to be two separate muscles in other groups of birds [4, 14, 22, 24].

Curiously, the $M$. protractor quadrati was found to be rudimentary in $P$. miniaceus, $P$. mentalis, $P$. puniceus, $D$. rafflesii, and $D$. javanense, while the $M$. protractor pterygoidei muscle was underdeveloped in the species from the genus Picus and more developed in D. rafflesii and B. rubiginosus. Because these muscles are powerful upper jaw retractors and play a decisive role in cranial kinesis in woodpeckers, it is difficult to understand their underdevelopment in those species. The ventral palatine fossa shelters the $M$. pterygoideus ventralis medialis, which is very well developed in woodpeckers and acts as a powerful upper jaw retractor in birds. van Gennip [20] is one of the few authors who have described this fossa and correlated it with the origin and development of this muscle. The other authors who studied the Columbidae $[14,25]$ did not mention this structure, as they only compared the development of the muscles among the species of this family. According to Bock [6], "the mass and shape of the palate are apparently correlated with the size and power of the upper jaw and with the strength of the muscles. Many of the exact details of this correlation must still be ascertained." Morioka [26] concluded that the development of the associated muscle mass and upper jaw retraction power is also increased when this fossa is deeper. However, this author observed that an underdeveloped muscle mass in the Apodidae allowed for greater speed in closing the beak at the expense of what the author called a powerful biting force. Among the woodpeckers studied here, this structure is relatively noticeable and deep in $B$. rubiginosus, which is the smallest species in the Picini tribe. At the same time, the muscles originating in this fossa, the M. pterygoideus ventralis medialis, and lateralis are more developed in this species, as Bock [6] predicted and Morioka [26] confirmed.

The pterygoideus system was found to exhibit a relatively high degree of structural diversity both in the woodpeckers studied in this investigation and in a study previously performed by the same group [5]. This observation was also made by Merz [14], Rooth [25], and van Gennip [20] in the Columbidae and other groups of birds [19]. This variation typically manifests as differences in the main aponeuroses and the arrangement and direction of the fleshy fibers of each muscle in the system. D. javanense has a venter externus in the pterygoideus ventralis lateralis muscle that was not observed in the rest of the species studied. This finding is similar to the observations that Donatelli [5] made for Melanerpes cruentatus and Mesopicus griseocephalus. However, Donatelli 
[5] also reported that the major structural differences observed in the pterygoideus system of woodpeckers are also present in Jynx ruficollis.

Based on this analysis one may conclude the following: (1) there is a clear association between the ventralis lateralis and dorsalis lateralis muscles through fleshy fibers that are connected in all species; (2) the jaw musculature of the genus Picus differs from that of other Picini genera in terms of the poor development of the protractor muscle system of the quadrate (M. protractor quadrati and M. protractor pterygoidei); (3) generally, the M. pseudotemporalis superficialis originates in the ventrocaudal region of the laterosphenoid (the lower part of the orbit), with the only noteworthy exception being an origin in the upper part of the orbit in Dinopium javanense; (4) the protractor pterygoidei muscle is more developed in Blythipicus rubiginosus, Dinopium rafflesii, and $D$. javanense than the other species.

The Picini in general showed strong primary jaw protractors (M. protractor quadrati and M. protractor pterygoidei), and also for secondary jaw protractors (pterygoideus system, mainly the $M$. pterygoideus dorsalis lateralis and the $M$. pterygoideus ventralis lateralis). Muscles of the adductor mandibular system are quite variable but much more complex whether one compares with other groups of birds.

\section{Acknowledgments}

The author is very indebted to Martjan Lammertink, who collected the woodpecker species and provided them to him to study in detail. The author is very grateful to the Museum Zoologicum Bogoriense, the Indonesian Institute of Sciences (LIPI), and the Natural History Museum of the Indonesian Institute of Sciences (MZB), Indonesia, for loaning him the Picini for anatomical studies. The author also would like to thank the National Museum of Natural History (USNM), Smithsonian Institution, Washington DC, USA for allowing him to visit their collection and study the Picidae. The author also would like to thank France Pereira for her magnificent illustrations of the jaw musculature.

\section{References}

[1] H. Winkler, D. A. Christie, and D. Nurney, A Guide To the Woodpeckers, Piculets and Wrynecks of the World, Pica Press, Robertsbridge, UK, 1995.

[2] W. J. Bock, "Functional morphology of the woodpecker feeding apparatus," in Vertebrate Functional Morphology, H. M. Dutta and J. S. D. Munshi, Eds., pp. 295-314, Science Publishers, Enfield, NH, USA, 2001.

[3] H. Winkler and D. A. Christie, "Family Picidae (woodpeckers)," in Handbook of the Birds of the World, J. del Hoyo, A. Elliot, and J. Sargatal, Eds., vol. 7 of Jacamars to Woodpeckers, pp. 296-555, Lynx Editions, Barcelona, Spain, 2002.

[4] L. P. Richards and W. J. Bock, "Functional anatomy and adaptative evolution of the feeding apparatus in the Hawaiian Honeycreeper genus Loxops (Drepanididae)," Ornithological Monographs, vol. 15, pp. 1-173, 1973.

[5] R. J. Donatelli, "The jaw apparatus of the neotropical and of the afrotropical woodpeckers (Aves: Piciformes)," Arquivos De Zoologia, vol. 33, pp. 1-70, 1996.
[6] W. J. Bock, "Kinetics of the avian skull," Journal of Morphology, vol. 114 , pp. 1-52, 1964.

[7] J. C. V. Berge and G. A. Zweers, "Myologia," in Nomina Anatomica Avium, J. Baumel, A. S. King, J. E. Breazile, and H. E. Evans, Eds., pp. 189-247, Academic Press, London, UK, 1993.

[8] R. A. Bams, "On the relation between the attachment of the jaw muscles on the surface of the skull in Podiceps cristatus L., with some notes on the mechanical properties of this part of the head," Proceedings of the Koninklijke Nederlandse Akademie Van Wetenschappen, vol. 59, pp. 82-101, 1956.

[9] W. J. Beecher, "Feeding adaptations and systematics in the avian order Piciformes," Journal of the Washington Academy of Sciences, vol. 43, pp. 293-299, 1953.

[10] F. H. Edgeworth, The Cranial Muscles of Vertebrates, Cambridge University Press, London, UK, 1935.

[11] H. Hofer, "Zur Morphologie der Keifermuskulatur der Vogel," Zoologische Jahrbücher. Abteilung Für Anatomie Und Ontogenie Der Tiere, vol. 70, pp. 427-600, 1950.

[12] E. Höfling and J. P. Gasc, "Biomécanique du crâne et du bec chez Ramphastos (Aves, Ramphastidae)," Gegenbaurs Morphologisches Jahrbuch, vol. 130, pp. 125-147, 1984.

[13] T. Lakjer, Studien über die Trigeminusversorgte Kaumuskulatur der Sauropsiden, C. A. Reitzel Buchlandlung, Copenhagen, Denmark, 1926.

[14] R. L. Merz, "Jaw musculature of the mourning and whitewinged doves," University of Kansas Publications, Museum of Natural History, vol. 12, pp. 521-551, 1963.

[15] R. W. Sims, "The morphology of the head of the Hawfinch, Coccothraustes coccothraustes with special reference to the myology of the jaw," Bulletin of the British Museum of Natural History, Zoology, vol. 2, pp. 370-393, 1955.

[16] D. Starck and A. Barnikol, "Beuiträge zur Morphologie der Trigeminusmuskulatur der Vögel," Morphologisches Jahrbuch, vol. 96, pp. 14-72, 1954.

[17] R. L. Zusi, "Structural adaptations of the head and neck in the black-skimmer Rhynchops nigra," Publications of the Nuttall Ornithological Club, vol. 3, pp. 1-101, 1962.

[18] P. J. K. Burton, "Feeding and the feeding apparatus in waders," Bulletin of the British Museum (Natural History), vol. 719, pp. $1-50,1974$.

[19] P. J. K. Burton, "Anatomy and evolution of the feeding apparatus in the avian orders Coraciiformes and Piciformes," Bulletin of the British Museum of Natural History, Zoology, vol. 47, pp. 331-443, 1984.

[20] E. M. S. J. van Gennip, "The osteology, arthrology and myology of the jaw apparatus of the Pigeon (Columba livia L.)," Netherlands Journal of Zoology, vol. 36, pp. 1-46, 1986.

[21] R. L. Zusi, "A functional and evolutionary analysis of rhyncokinesis in birds," Smithsonian Contributions to Zoology, vol. 395, pp. 1-40, 1984.

[22] G. A. Zweers, "Structure, movement and myography of the feeding apparatus of the mallard (Anas platyrhynchos L.). A study in functional anatomy," Netherlands Journal of Zoology, vol. 24, pp. 323-467, 1974.

[23] R. J. Donatelli, "Cranial osteology and mycology of the jaw apparatus in the Galbulidae (Aves: Piciformes)," Arquivos De Zoologia, vol. 32, no. 1, pp. 1-32, 1992.

[24] R. L. Zusi and R. W. Storer, "Osteology and myology of the head and neck of the pied-billed grebes (Podilymbus)," Miscellaneous Publications, Museum of Zoology, University of Michigan, vol. 139, pp. 1-49, 1969.

[25] J. Rooth, "On the correlation between the jaw muscles and the structure of the skull in Columba palumbus palumbus 
L," Proceedings of the Koninklijke Nederlandse Akademie Van Wetenschappen, vol. 56, pp. 251-264, 1953.

[26] H. Morioka, "Jaw musculature of swifts (Aves, Apodidae)," Bulletin of the National Museum of Natural Science, vol. 17, pp. 1-16, 1974. 

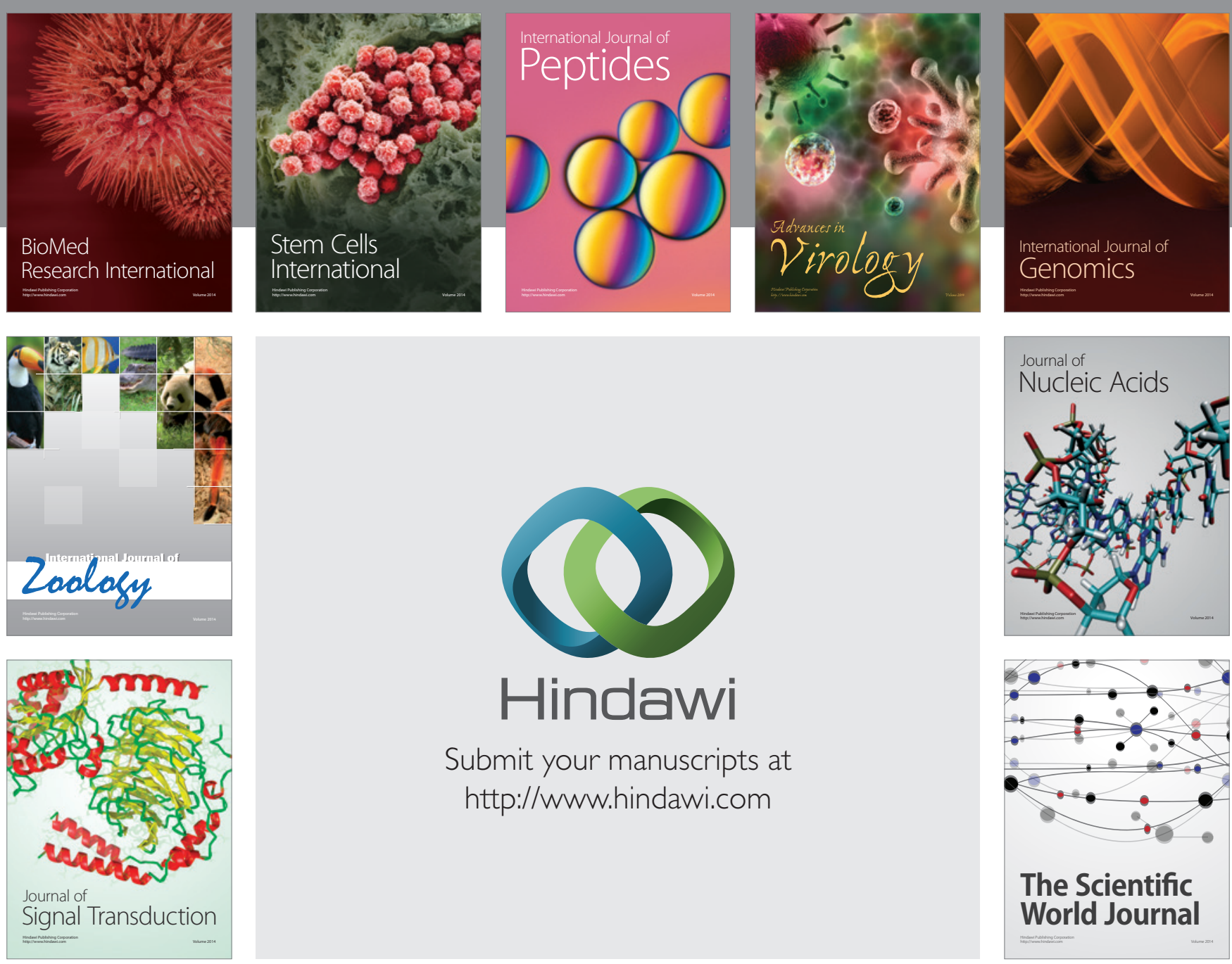

Submit your manuscripts at

http://www.hindawi.com
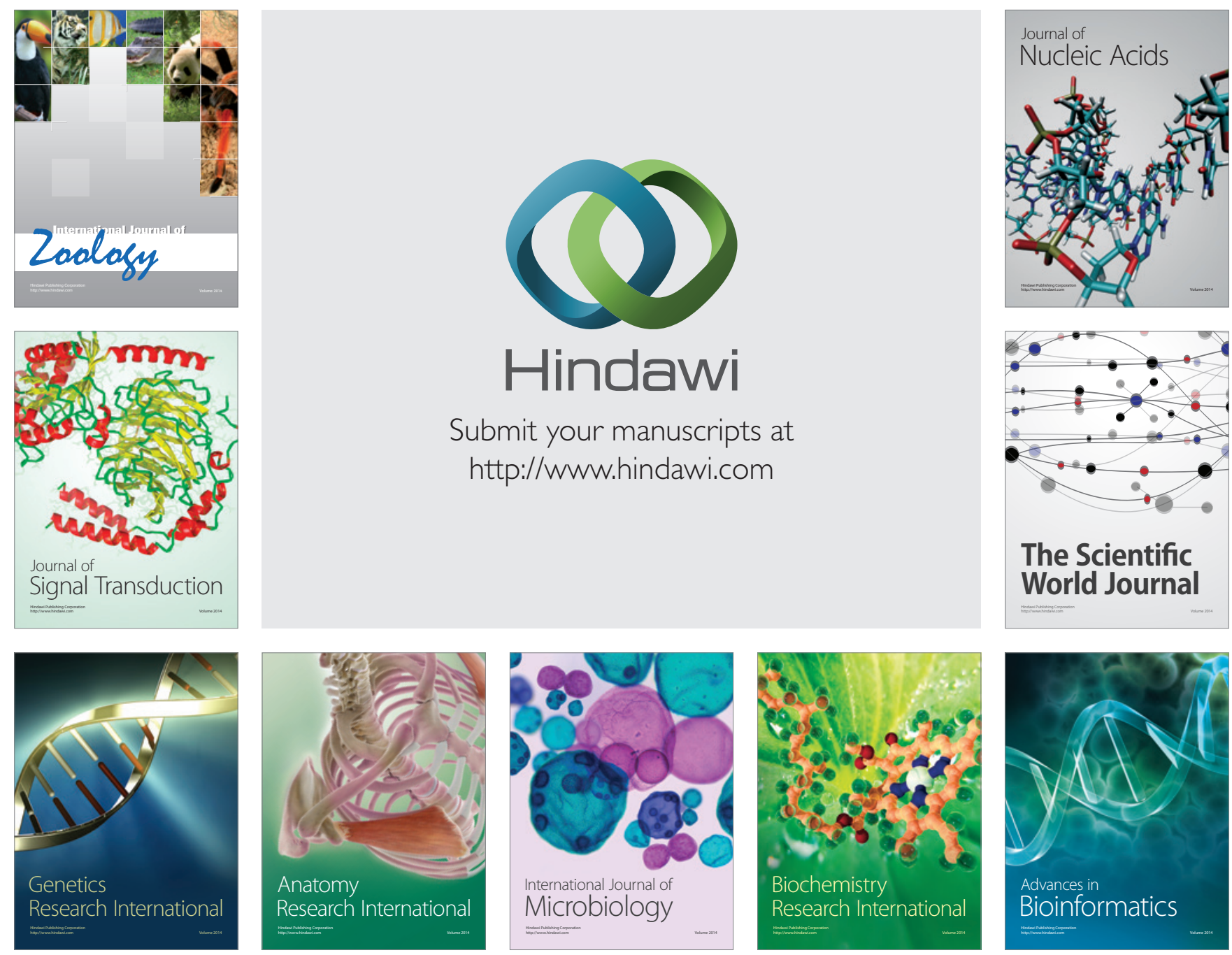

The Scientific World Journal
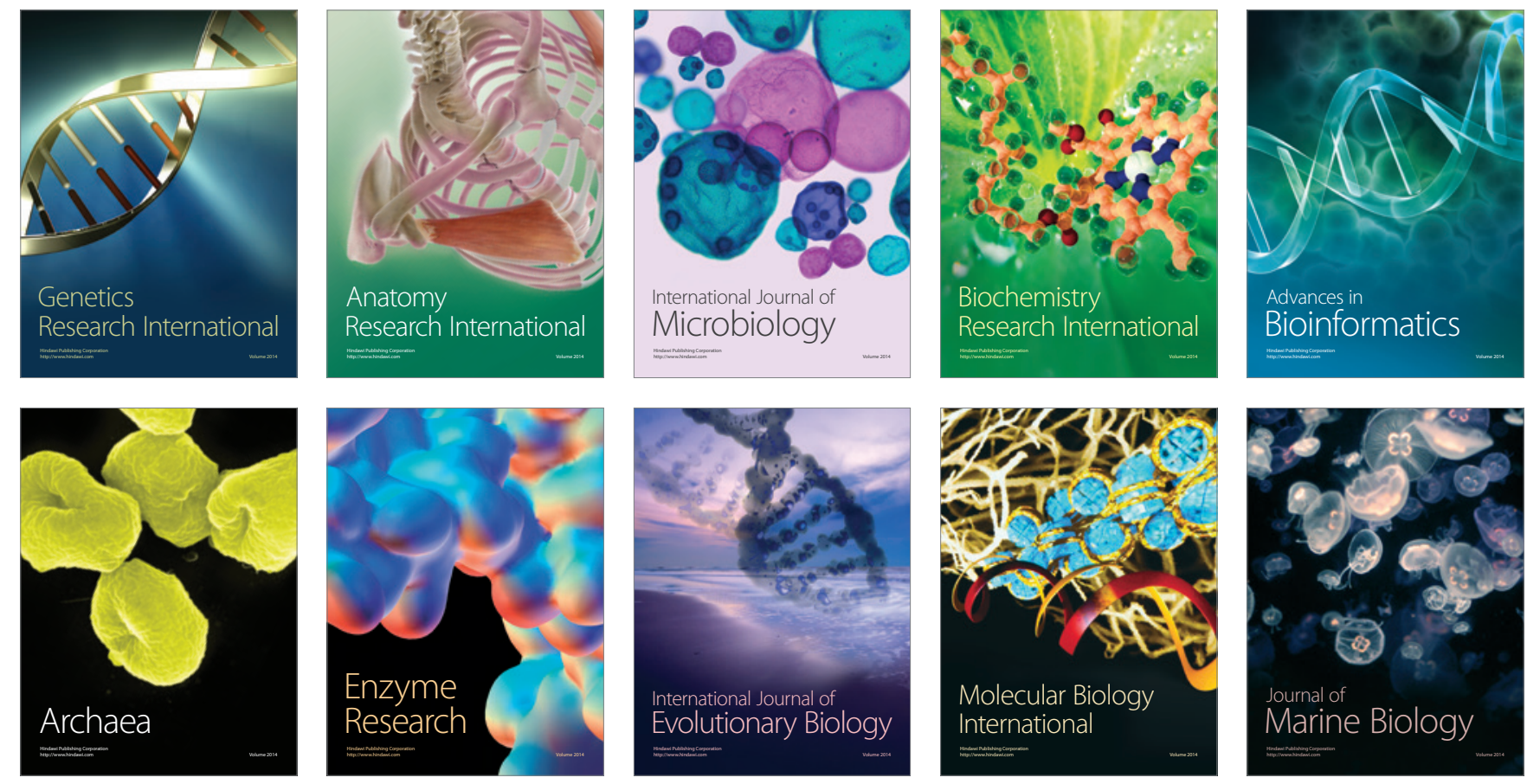